\title{
Pheochromocytoma and Paraganglioma pT3 TNM Finding v8
}

National Cancer Institute

\section{Source}

National Cancer Institute. Pheochromocytoma and Paraganglioma pT3 TNM Finding v8. NCl Thesaurus. Code C141123.

Tumor of any size with invasion into surrounding tissues (e.g., liver, pancreas, spleen, kidneys). (from AJCC 8th Ed.) 